\title{
The co-production of a "relevant" expertise - administrative and scientific cooperation in the French water policies elaboration and implementation since the 1990s
}

\author{
J. F. Deroubaix \\ Centre d'Enseignement et de Recherche Eau-Ville-Environnement - Ecole Nationale des Ponts et Chaussées, \\ Champs-sur-Marne, France
}

Received: 10 July 2007 - Published in Hydrol. Earth Syst. Sci. Discuss.: 8 October 2007

Revised: 16 June 2008 - Accepted: 21 June 2008 - Published: 26 August 2008

\begin{abstract}
This paper aims at understanding the social and political uses of the principle of integrated management and its possible impacts on the elaboration and implementation processes of public policies in the French water management sector. The academic and political innovations developed by scientists and agents of the administration these last 25 years are analysed, using some of the theoretical tools developed by the science studies and public policy analysis. We first focus on the construction of intellectual public policy communities such as the GIP Hydro systems, at the origin of large interdisciplinary research programs in the 1990s. A common cognitive framework is clearly built during this period on the good governance of the aquatic ecosystems and on the corresponding needs and practices of research. The second part of the paper focuses on the possibilities to build political communities and more or less integrated expertises in the decision making processes concerning various issues related to water management. Eutrophication and its inscription on the French political agenda is a very significant case for analysing the difficulty to build such a political community. On the contrary, when there is an opportunity for policy evaluation, which was the case concerning the management of wetlands in France or the implementation of compulsory flows on the French rivers, these communities can emerge. However, the type of integrated expertise and management proposed in these cases of policy evaluations much depends on their methodological choices.
\end{abstract}

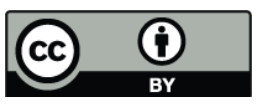

Correspondence to: J. F. Deroubaix (jfd@cereve.enpc.fr)

\section{Introduction}

\subsection{Context}

New modes of public action have been experimented these last decades, essentially oriented towards the search for a consensus among the concerned social groups and a good balance between the economic and social interests impacted. This evolution is particularly evident in researches focused on the transformation of the role of the central State (Duran and Thoenig, 1996; Leca, 1996). This transformation led to new interactions between the central State, the local governments and private actors such as non governmental organisations. Negotiation, partnership and contract constitute new modes to build the "common good" and to conduct public policies (Fontaine and Hassenteufel, 2002). Environmental policies are probably the most advanced field of experimentation of these new ways to conduct public policies which can be referred to under the key word "integrated management" (Callon et al., 2001; Lascoumes and Le Bourhis, 1998).

Yet, giving a unique and exclusive definition of integrated environmental management would be a worthless task. The European Water Framework Directive (WFD, directive 2000/60/CE, December 2000) establishes, for the state members, a duty of "good ecological status" for their surface waters. Nevertheless there is no clear and explicit definition of this "good status", neither in the text itself, nor in the various instruments of public policies listed in the WFD: territorial planning (Articles 5, 11 and 13), public participation (Article 14), economic assessment (Article 4),

Published by Copernicus Publications on behalf of the European Geosciences Union. 
identification of priority pollutants (Article 16$)^{1} \ldots$ Then how can one explain the constant political and administrative reference to the so called standard of integrated management?

\subsection{Problematic}

First of all, who exactly are the social and political actors who are committed to implement this integrated management? In this paper, we try to understand the social and political uses of this concept and its possible impacts on the development and implementation of public policies processes.

To be fully understood, integrated management in environment (and more specifically in water management) has to be linked with two other issues: the crisis of democracy and the role of experts in politics. The emergence of new types of risks, the increasing number of actors involved in the decision making process, have led to question the ability and legitimacy of experts "to tell the truth". In this context, the public power has in the last decade been seeking for new ways of decision making. Public authorities tried, in particular, to involve the general public while turning towards new modes of research, no more based on specific knowledges raising the issue of interdisciplinarity (Nelkin, 1992). We analysed the academic and political innovations developed by scientists and agents of the administration in the French water management sector, using some of the theoretical tools developed by science studies and public policy analysis. On the one hand, those science studies have ultimately showed that science is not an autonomous activity ${ }^{2}$, and following this interpretation, we propose to consider the expertise and the experts in the water management sector not as an in-between public action and research practice but, on the contrary, as an achievement of the internal logics of these two social activities. On the other hand, public policy analysis has established that policy making processes are characterised by the participation of larger policy networks than in the past times. Some authors use the terms of "policy communities" or "issue networks" to designate this phenomenon,

\footnotetext{
${ }^{1}$ These priority pollutants should incorporate at least the 33 substances listed in the decision no. 2455/2001/CE (20/11/2001) of the European Parliament and European Council (modifying the Directive 2000/60/CE).

${ }^{2}$ Social Studies of Science have, since the seventies, put the emphasis on the processes of construction of scientific facts. The everyday work of scientists, the funding of science, the organization of scientific communities and the regulation of the scientific field, the modes of data production and the building processes of scientific theories, the diffusion and reception of these theories and their impacts on the technological innovations have been investigated. The scientific activity in that tradition is considered as a social activity even if it is constructed as independent from the social and political realm of interests. For a better understanding of the transactions and corresponding processes of "purification" in between politics and science see Latour (1989) and Stengers (1993).
}

depending on the level of coherence of the network and interdependence of its members (Gaudin, 1999). These networks produce, at the same time, the cognitive framework that enables the translation of social concerns into manageable issues, and the political compromises which are embedded in the decision. Taking into account not only this production of meaning but also integration of interests in the public action, Sabatier (1999) built the concept of a "policy frame" to design an approach in which he could relate the changes as a result of an "advocacy coalition's" work. In the case of French water management, we distinguished two different types of policy communities: on the one hand, the intellectual one, more oriented towards the production of a collective meaning on the right way to produce the scientific knowledge and on the fairest way to reach a consensus on their management; on the other hand, the political one, more oriented towards the building of compromises on issues inscribed on the political agenda. Crossing those two approaches, we are aiming at avoiding taking part in the recurring controversy of what is "real" integrated water management. In order to suspend such a controversy, we can temporarily define integrated management as a type of management aiming at satisfying all kinds of needs by limiting the competition between the various uses and protecting as strongly as possible the environment at an acceptable cost for the community (Valiron, 1984). This aim necessitates a decision making process which enables, through a negotiation, a common understanding and an integration of the various interests of the concerned stakeholders (Mermet, 1991).

Intellectual and technical tools as well as institutional facilities, created in order to promote such an integrated management, were analysed from two perspectives, corresponding to the two parts of this paper:

- We first investigated the discourses defining the "fair" governance practices and the "relevant" forms of research on the aquatic ecosystems. These types of discourses are produced from places such as conferences involving managers and scientists, editorial boards of engineering reviews... In this case, we will talk about "intellectual" public policies communities (Jordan, 1990; Jordan and Richardson, 1987).

- In the second movement of the demonstration, we proposed an analysis of the "political" communities built by scientists and administration agents which aim at raising new issues and design new policy instruments in the water management sector.

\subsection{Methods and material}

Three case studies were conducted in order to investigate these intellectual and political public policy communities. The first case study is a French research network on hydro systems; the second one is the controversy about eutrophication and the programs launched in the 1990s in France in 
order to reduce it, and the third one is a comparison between the processes of evaluation and design of, on the one hand, a program of management of French wetlands and, on the other hand, the regulation of water flows imposed to French hydraulic electricity plants. In the first case study we were able to produce interesting material in order to understand the institutionalisation process of an intellectual public policy community (Sect. 2) whereas the other considered issues offered to the analysis a good range of situations in order to formalise the possibilities for administrative agents and scientists to build political public policy communities. The management of wetlands and the programs implemented in order to reduce eutrophication corresponded to cases of new public policy issues, whereas the case of rivers flows was an old and controversial issue coming back from time to time on the governmental agenda (Sect. 3).

In these three cases, we interviewed the key actors who took part in the formalisation of the problem. We tried to get from them the story (which is not necessarily the official one) of how they dealt with the problem and the corresponding uncertainties. We paid attention to the documents produced, took into consideration the data collected by the policy makers and, also, the processes of transformation of these data from one report to another. In addition to this material, we considered the legislation and regulation adopted on the three issues.

\section{Intellectual public policy communities and the pro- duction of an integrated discourse on governance and research on hydro systems}

To test the hypothesis that discourses on the integration of research and public action in the water management sector are, first of all, produced by an intellectual public policy community formed by scientists and civil servants in charge of the water policy development and implementation, we observed that community at work. We studied more specifically one of its most institutionalised forms: a network of researchers on hydrosystems, structured by the French ministry of Environment in the late 1990s: the Group of Scientific Interest for the Research on Hydro systems (GIP-Hydrosystèmes). This group launched during the late nineties seven different interdisciplinary programs of researches (involving each of them five to ten different researches during a period of several years, four years on average): the first program dealt with the economic benefits due to hydrosystems; the second with the flooding risk; the third one was about the biodiversity and the functionalities it could play in the continental ecosystems; the fourth one was on the biological parameters; the fifth on the management of wetlands; the sixth one was dedicated to radars and their possible uses in weather forecasts; while the seventh one aimed at coordinating existing and future research in specific areas. These programs were quite typical of the large French interdisciplinary programs in environment
(PIREN) implemented since the seventies ${ }^{3}$. What were the transactions that took place between the scientific and administrative fields in this network and during these programs? In all of them, the researches conducted aimed at understanding the relations between the environmental elements and the induced risks rather than elaborate environmental protection strategies. The first significant characteristic of this intellectual community was therefore that all its members shared a strongly structured definition of the environment. The environment being studied was and had to be human centred. Therefore, it is the pollution and its impacts on the human activities that had to be investigated and revealed. This intellectual posture is similar whatever type of knowledge one considers: hydrologists worked on the transfer of pollutants, biologists were analysing the evolution of the fish stocks, and economists were looking at the benefits resulting from hydrosystems; but all of them shared the same vision of environment either as a context or a product of the human activity. This perception, so commonly shared, even by the present author, had to be clearly explicated, as it might not correspond to the vision of users of the aquatic eco-systems, for instance some of the Non Governmental Organisations who claim for an environmental protection, for "the nature itself" and not because of a determined functionality of the environment. The claim for such a vision of environment and environmental sciences was a way to set a clear frontier for this intellectual policy community. The calls for proposals were very explicit on this way to consider environment and interviews revealed that scientists strongly agreed on it. This was even more important as the second characteristic of this network was that its members viewed the research as the result of the meeting of a social demand and a supply of science. This perception of the research work was particularly acute in the administrative literature presenting these programs (see, in particular, http://www.oieau.fr/hydrosys/gip.htm) and the GIP was presented itself as the place were the meeting was made possible. The institutional building of the group was thought in order to perform this meeting. Two bodies ruled the GIP-Hydrosystems: an administrative board and a scientific council. Representatives of the administrations together with scientists were placed in the situation to tell the best way to answer the scientific demands of the society.

As we will see, what occurred there was more complex than the official presentation done by scientists and administrative agents. It was a pragmatic coordination of the existing structures of research on the environment.

One of the main innovations of these programs was the experimentation of a territorial organisation of the research on hydro systems and especially the one on wetlands. Several watersheds were chosen as priority areas for research

\footnotetext{
${ }^{3}$ The program on hydro systems took place after a set of quite similar programs (since 1978 and the first PIREN). For a more detailed description of the co-construction of an environmental research policy in France, see Neboit-Guilhot and Davy (1996).
} 
Table 1. Distribution of the seven programs of the GIP Hydro systems.

\begin{tabular}{|c|c|c|}
\hline Title of the program & Disciplines & Integration of the disciplines \\
\hline $\begin{array}{l}\text { Economic Assessment of the benefits due } \\
\text { to hydro-systems }\end{array}$ & Social science & $\begin{array}{l}\text { Economy is the exclusive branch of know- } \\
\text { ledge mobilised }\end{array}$ \\
\hline Flood Risks & $\begin{array}{l}\text { Multidisciplinarity } \\
\text { (Hydraulics - Hydrology - Geography - } \\
\text { Management - Political Science - Sociol- } \\
\text { ogy and Psychology - management) }\end{array}$ & $\begin{array}{l}\text { There is no coordination between the vari- } \\
\text { ous branches of knowledge }\end{array}$ \\
\hline Territorial Research & $\begin{array}{l}\text { Multidisciplinarity } \\
\text { Physics - chemistry - biology and socio- } \\
\text { economy }\end{array}$ & $\begin{array}{l}\text { The coordination is done through a territo- } \\
\text { rial approach, the collected data being the } \\
\text { first material for a body in charge of as- } \\
\text { sessing the "quality" of a watershed }\end{array}$ \\
\hline $\begin{array}{l}\text { National Program of Research on Wet- } \\
\text { lands }\end{array}$ & $\begin{array}{l}\text { Interdisciplinarity } \\
\text { Social science (sociology - law - eco- } \\
\text { nomics) and "hard science" (Biology - Ge- } \\
\text { ology) }\end{array}$ & $\begin{array}{l}\text { Some topics are exclusively considered } \\
\text { through one or two branches of the "hard } \\
\text { science"; some topics constitute a real at- } \\
\text { tempt to integrate social science studies } \\
\text { and hard science. Nonetheless, in this } \\
\text { last case, the integration consisted more } \\
\text { in integrating existing studies related to } \\
\text { one specific site rather than investigate on } \\
\text { an issue using various branches of know- } \\
\text { ledge. }\end{array}$ \\
\hline Biological Parameters & Natural science (Biology) & $\begin{array}{l}\text { Biology is the exclusive branch of know- } \\
\text { ledge mobilised }\end{array}$ \\
\hline $\begin{array}{l}\text { Functional Role of Biodiversity in the } \\
\text { Continental Aquatic Ecosystems }\end{array}$ & $\begin{array}{l}\text { Natural science (Ecology - biology - } \\
\text { chemistry - geology) }\end{array}$ & $\begin{array}{l}\text { The integration of the various branches of } \\
\text { knowledge of the hard science is partly re- } \\
\text { alised through modelling tools }\end{array}$ \\
\hline $\begin{array}{l}\text { Meteorological Radars for the prevision of } \\
\text { floods and the management of sewage net- } \\
\text { works }\end{array}$ & $\begin{array}{l}\text { Natural science (Engineering - hydrology } \\
\text { - meteorology - mathematics) }\end{array}$ & $\begin{array}{l}\text { Integration through a technical device (the } \\
\text { system of alert) of the different branches of } \\
\text { the hard science mobilised }\end{array}$ \\
\hline
\end{tabular}

and observation. The researches used hydrology, biology, chemistry, but also social sciences. Moreover, they had the objective to put into coherence the newly produced data with the existing ones. One can, then, say that there was a clear political willingness to bring more coherence in the available expertise, useful for the elaboration and implementation of the public programs. At the same time there was a necessity to separate the activities of research and the ones of government. This appears clearly when looking at the institutional building in this network: two councils officially ruled the program, one administrative and the other scientific. Further investigation showed that both councils were mixed and characterised by a mere representation of the administration. The administration board was composed of the representatives of the main research organisations working on the subject of continental waters (10) and of the ministry of Environment (2) and the ministry of Research (1). This administrative board was characterised by a "representative" legitimacy. Its members represented the organisation they be- longed to. The scientific council, on the contrary, was characterised by a legitimacy based on scientific knowledge. Its members, mostly researchers but also civil servants from the ministry of Environment and the ministry of Public Works, were designated by the administrative board, but were considered as totally independent from their research centre or administrative department.

In these conditions, it was not very surprising that the coherence in between the researches was in fact built afterwards. On the first hand, as it appears in the Table 1, the programs consisted more in a collection of researches related to one specific type of knowledge rather than integrated researches dealing altogether with one specific issue. On the second hand, there were types of knowledge much more funded than others (hydrology and biology for natural hard sciences and economy for social sciences). Among the seven programs only one was exclusively devoted to social sciences and more precisely to economy. Three of these programs could be considered as multidisciplinary or 
interdisciplinary and three others exclusively involved biologists, hydrologists, geologists, and engineers with various backgrounds (chemistry, mathematics...). The financial dimension is important as it showed to what extend the intellectual policy community succeeded in promoting a new mode of research. Definitely, the repartition of the subsidies within the various programs revealed that the opportunities of dialog and cooperation between the disciplines were not so important. Nonetheless, all these researches had in common a prescriptive dimension (rather than a descriptive one) and the researches involving modelling tools were preponderant. Of course, prescriptive results were not inherent to the modelling tools and the most prescriptive research program, the one on wetland management, did not involve such tools; but the way these modelling tools were to be used, not only to formalise "natural" processes but to predict trends resulting from pressures on hydrosystems, should have led to prescriptive results. The case of the research program on the wetlands was very emblematic of the common concern of the researchers and of the administrative agents in this intellectual community. It has to be a bit detailed in order to understand its characteristics, both interdisciplinary and prescriptive. Wetlands was an old subject of research for scientists working on this issue, but the way to characterise them as potential "natural infrastructures" (e.g. territories which could be useful for flooding protection, diffuse pollution abatement, etc.) was quite an innovative point of view. From a public management point of view, these wetlands were a new object of concern. The Law on water management of 3 January 1992 stated for the first time that their existence should be preserved, without creating any specific policy instruments. Therefore this program of research on wetlands management was probably the most interdisciplinary one and was clearly oriented towards a prescriptive objective: as the call for propositions mentioned "The program should enable the deciders to design and validate methodologies for protection, management or restoration of wetlands". This prescriptive objective was explicitly present in some of the funded researches such as the one aiming at elaborating the rules of management of the superficial waters in order to promote an integrated development of wetlands boarding the Atlantic.

A cognitive framework was undoubtedly settled while this kind of research programs was developed: (a) the relevant scale for good research and the relevant territory for good governance is the watershed; (b) "policy entrepreneurs" from the administration and scientists shared a preference for prescriptive researches (and especially tools incorporating modelling). These tools should have enabled the stakeholders to get a clear view of the trends under a set of limited scenarios. The vision of the "good governance" behind this type of tools was that the uses of the ecosystems should have been negotiated between the various users in order to maximise the preservation of the resource.

The concept of "intellectual public policy community" is interesting for understanding how a group of administrative agents and scientists built a cognitive framework consisting in a common perception of the environment and of the good governance, and shared view of the best way to conduct the research on the aquatic ecosystems. We have shown that this cognitive framework, in fact, led rather to a collection of specific studies than to a coherent set of tools enabling, for instance, to assess the impact of planning projects on wetlands. But the important thing was that these policy entrepreneurs benefited new reasons for a public action fostering ecological preservation rather than legitimate tools for effective public choice.

This statement raises the question of the benefits for the members who belonged to that community. Building that community, and sharing the described cognitive framework, the members undoubtedly benefited an extra of legitimacy for their own specific activities. This extra was possible because, at the end of the process, the research program appeared as the meeting of a demand (coming from the civil society) and of a supply (coming from the scientific community), even though the detailed analysis of the community revealed that this meeting was not so obvious. The discourse on "integrated water management" was a way for the members of the "policy community" to perform, whatever their identity, different roles: they could be, at the same time, provider or user of science, or mediator between users and providers of scientific expertise. The provider of science could, for instance, be a scientist working for the university, or an expert in a technical department of an administration, or in the department of research of the French electricity company, or a private consultancy, less often, someone working in a technical department of a municipality, or a representative of a NGO working in the field of environmental protection.

On the contrary, except those few providers of science who could, at the same time, be potential users, there were no representatives of other users. According to the providers and mediators, the users were always the ones who, outside the community, were asking for such or such research and who might have benefited the results. For instance, no representative of local governments (regions, counties or municipalities which play a key role in France in the planning and in the management of the water resource and of the hydrosystems), nor representatives of the fishers or of the consumers, nor professionals of the drinkable water and sewage sectors were involved in the definition of the "social demand" of research. Except in the restitution conferences, organised at the end of the programs, more widely open to all types of actors, there were the members of the intellectual community (scientists and administrative agents) who expressed themselves in the name of these users and formalised this "social demand". The performance here consisted in the simultaneous construction of a supply and a demand of research, in the name of potential users. The social utility of the researches was guaranteed because of the distinction in the roles, no matter if the provider of the expertise is also a potential user 
or a mediator.

The standard of integrated water management had to be considered, in a first movement, as the product of one of the most explicit forms of cooperation between scientists and administrative agents. We showed that this cooperation resulted in the construction of a collective cognitive framework integrating the best way to promote good governance and to conduct the research on aquatic ecosystems. The standard of integrated water management is moreover a way for the scientists to legitimate their researches, and for the environmental administration to find new reasons for the public policies they are in charge of.

This first movement is however not sufficient to understand the various uses of the standard and it was necessary to analyse the conditions of its implementation when administrative agents and scientists were involved in the "daily" decision-making process.

\section{Political public policy communities and the use of ex- pertise in the construction of water management poli- cies}

This section consists in an analysis of the expertise required in the processes of policies and programs elaboration itself. We focus on the reduction of pollution policies (eutrophication) and on two issues that were subject to a policy evaluation (policies for wetland management and the regulation of flows for hydraulic electricity plants). The purpose here is to analyse the cooperation between administrative agents and scientific experts developed in order to build political communities. Of course the performance is much more complex when the cooperation deals directly with political decision and no more with elaborating a coherent discourse on the relevance of doing something and doing it the right way. The possibility to build these political communities depends on the political opportunities offered by the structure of the French political organisation. This structure of political opportunities can be roughly understood as the capacity of a political structure to respond to and to integrate social claims (McAdam et al., 1996). The capacity will highly depend on the lack or on the existence of procedures that enable the governmental organisations to take into consideration the social movements. Considering the notion the other way round, we can define it as the ability of an actor or a coalition of actors to use the existing political procedures in order to change the governmental agenda (Garraud, 1990). In the three examined cases, the capacity for producing an integrated expertise relies on a structure of political and technological opportunities at a national and territorial level.
3.1 The expertise dependant on the organisation of the water management sector: the case of eutrophication in France since 1988

In the case of eutrophication, policies were implemented according to pre-existent routines steadily embedded in the organisation of the French water management sector. The territorial planning procedures did not really succeed in changing the main distinction between agricultural and urban inputs to the ecosystem. Let's go back to the late 1980s and beginning of the 1990s and remind the process of expertise that took place during the elaboration and implementation of policies aiming at reducing the phenomenon of eutrophication. The issue of eutrophication appeared in France on the governmental agenda in 1988. By that time the monitoring of the superficial waters concerning eutrophication was far from being fully implemented and the scientific controversies concerning the best way to regulate the phenomenon were far from being stabilised. And suddenly in 1988, the problem of eutrophication became a problem of pollution involving Nitrogen (from agriculture) and Phosphorus (from urban areas). Here is a classical example of a process of coordination of a pre-existing solution and a raising problem that has been early formalised in the public policy analysis (Edelman, 1991). Indeed, let's consider the political context in 1988. The government started to consider the issue when Rhône Poulenc, the main French manufacturer of detergents was blamed for worsening eutrophication, by its Anglo-Saxon competitors, who no more used phosphates. Rhône Poulenc decided to raise a controversy about the toxicity of the products used as substitutes to phosphates. The ministry of Environment did not close the controversy but, relying mainly on a single expertise of Carbiener (1990), scholar of the University of Strasbourg specialised in pharmaceuticals, the administration called for a progressive abatement of the phosphates in detergents and integrated Phosphorus (and Nitrogen) in the list of "pollutants" which had to be drastically reduced. The solution was technically and financially plausible. The French industry had developed the processes for such pollution abatement, believing that there would have been a problem of toxicity and public health (rather than a problem of ecotoxicity and environment) with nitrates in the coming years (CSI, Lyonnaise des Eaux, 1996). The water agencies could subsidise the equipments.

The implementation of the public policies corresponding to the problem formulation was also completely dependant on what we propose to call a structure of political (and technological) opportunities. The definition of the vulnerable and priority areas as prescribed by the European directives Nitrates and Urban Waste Waters ${ }^{4}$ was done according to administrative routines. Civil servants from the environmental administration, in charge of defining the priority areas ac-

\footnotetext{
${ }^{4}$ Directive 91/676/CEE, December 1991, and Directive 91/271, May 1991.
} 
cording to the Urban Waste Waters directive, did not take into account the geography of vulnerable areas, designed by the civil servants of the ministry of Agriculture. The first ones considered that all the urban areas should be integrated, beginning by the towns located in the upstream parts of the watersheds; the second ones considered that the only reliable criteria was an established or forecasted excess of nitrates in the resource for drinkable water production. The integration of the agricultural sector in the system of the water agencies fees was also very typical of the weight of the pre-existent routines steadily embedded in the organisation of the French water management sector. The Nitrates directive imposed a standard of no more than $170 \mathrm{~kg}$ of Nitrogen per hectare due to breeding. This standard was in the French case linked with a system of fees and incentives for the biggest farms, inspired from the existing system of fees imposed to domestic or industrial pollutions ${ }^{5}$. It led to some control of the main sources of pollution of the agriculture but a very small concern for other practices generating diffuse pollutions, such as chemical fertilizing. The territorial planning procedures did not really succeed in changing the main distinction between agricultural and urban inputs to the ecosystem.

It took years before the government ordered a serious evaluation on the performances of the policies aiming at reducing the pollution generated by agricultural activities, known as the "Plan de Maitrise des Pollutions d'Origine Agricole" (PMPOA; literally, Program for the Control of Agricultural Pollutions) (Inspection Générale des Finances, Conseil Général du Génie Rural, des Eaux et Forêts, Comité Permanent de Coordination des Inspections, 1999) ${ }^{6}$. It is very recently that researchers, granted by the ministry of Environment, began working on the efficiency of the different types of policy instruments used to reduce agricultural pollutions (taxation, voluntary agreements, regulation) (Doussan, 2002).

The case of eutrophication is a good example of the way the structure of political opportunities may affect the forms and the uses of expertise in policy elaboration. The possibility to build an integrated expertise appears as highly depen-

\footnotetext{
${ }^{5}$ The implementation of fees in the agricultural sector was instead quite different from other sectors as the State subsidised heavily breeding farms (which sometimes exceeded their legal capacity) before they were integrated in the system of fees. This practice is obviously a strange way to implement the polluter-pays principle and have been considered by Brussels as an unfair practice of competition. In October 2003 , farmers contributed $0.2 \%$ to the total amount of the water pollution fees collected by the water agencies and benefited $7 \%$ of granted subsidies (Flory, 2003).

${ }^{6}$ The failure of this program finally led to its reform during the year 2001. After months of negotiation, the European Commission agreed on a new version of the PMPOA. The new regulation based on this agreement put more pressure on all types of farmers' practices - and not only on the runoffs due to breeding. Subsidies now require a change in the practices of fertilising and in the uses of pesticides.
}

dent on the structure of political opportunities. A policy window was opened during the late eighties due to the commercial controversy on harmful effects of detergents on the environment. Both the environmental and agricultural administrations were involved in the controversy but none of them tried to settle a political public policy community (including at least civil servants from various administrations and scientists from various disciplines) which could have produced an integrated expertise. The one who took the most important advantage of this policy window was probably the industrial sector of sewage which was able to propose to the municipalities, responsible for cleaning waste waters, the adequate processes (previously developed for drinkable water production). In the case of eutrophication, the lack of political public policy community, due to the structure of political opportunities (share of the responsibilities between the ministry of Environment and the ministry in charge of Agriculture, existence of the water agencies which "monopolised" the problem and reduced it to a problem of loads of Nitrogen and Phosphorus that could be regulated through a system of fees and subsidies) led to a lack of integrated expertise and probably to the condemnation of France by the European Court of Justice (23 September 2004) for its "narrow" definition of the sensitive areas in various basins (Seine-Normandie, Artois-Picardie, Loire-Bretagne and Rhône-MediterranéeCorse) and the insufficient standards of treatment in more than 100 agglomerations.

At the same time, embedded in the structure of political opportunities, there are procedures that can be used as good opportunities for administrative agents and researchers seeking for a change in the way to develop the knowledge and to manage the aquatic ecosystems. One of these procedures is the development of policy evaluation these last years (Perret, 2001; Kessler et al., 1998).

In the case of eutrophication, as shown in the previous narration, the lack of political community led to a critical deficit of integrated expertise. On the contrary, in the cases of the wetlands management and the regulation of river flows for hydraulic electricity plants, there were policy entrepreneurs who used existing policy evaluation procedures in order to promote their cause.

3.2 Public policy evaluation as an opportunity for political public policy communities: comparison of the wetland management and the river flows evaluations

The comparison of those two cases is very heuristic for understanding what type of integrated expertise was possible when a group of administrative agents and experts cooperated in order to implement a policy evaluation procedure.

The evaluation on wetlands management can be considered as an evaluation ex ante, implemented in order to formulate a program of management or at least a referential for such a management, instead the one on the compulsory river flows is an evaluation ex post, already planned in the 
law. The evaluation on wetlands management involved, right from the beginning, a wide range of concerned stakeholders instead, the one on river flows involved only, at the very beginning, the representatives of the ministry of Environment and experts from the CEMAGREF, a research centre depending on the ministry of Agriculture (Secrétariat d'Etat auprès du Premier Ministre chargé de l'Environnement et de la Prévention des risques technologiques et naturels majeurs - Centre National du Machinisme Agricole, du Génie Rural, des Eaux et Forêts, 1990). For the wetlands evaluation, the network involved scientists, experts from the environmental administration and representatives of environmental protection agencies (Comité interministériel de l'évaluation des politiques publiques, Commissariat au Plan, 1994).

The problem for the experts involved in the wetlands management evaluation was to materialise the very extensive definition of the wetlands as incorporated in the Law on water management of 3 January 1992. For the evaluation of compulsory river flows, the problem was to assess the relevance of the flows prescribed by the Law on fishery of 29 June 1984 and to tell the interest of implementing flows adapted to each river which could be changed during a year period.

If we look back at the origins of the procedures - and not at their implementation- in both cases, there were scientists and administrative agents, taking the opportunity of policy evaluation procedures, to build political communities. In the case of the wetlands, civil servants from the ministry of Environment, in collaboration with scientists (mostly belonging to the Museum d'Histoire Naturelle and to the Centre d'Etude des Systèmes Fluviaux, and for some of them linked to non governmental organisations in the field of environmental protection) decided to use the evaluation procedures institutionalised since $1990^{7}$. In the case of the river flows, there were the civil servants from the ministry of Environment, together with the scientific experts from the CEMAGREF who decided not only to assess the legal river flows stated by the law but also to open a discussion on the relevance of adopting variable flows according to the river regime. These political communities produced a rather integrated expertise, opening a new space for negotiation.

The characteristics of this negotiation were directly linked with the methodological choices used to build the expertises. Let's examine these methodologies developed and explicit the constraints that experts had to face in order to produce an integrated expertise. Of course the methodologies were completely different in one case and the other. In the case of

\footnotetext{
${ }^{7}$ Decree of 22 January 1990 formalising a procedure of policy evaluation and creating a Scientific Council of Evaluation. This system was reformed in 1998 through a decree turning the Scientific Council of Evaluation into a National Council of Evaluation, more widely open to representatives of local governments and representatives of social and professional organisations. Although, the scientific sector and the central State administrations stayed overrepresented and kept the monopole of decision to launch the procedure.
}

river flows, the methodology developed by the CEMAGREF consisted in a modelling tool aiming at predicting the preference of the fish for different types of habitats, depending on the flow (and not on pollutions or floods) (Souchon and al., 1989). In the case of wetlands, the methodology consisted mainly in aggregating the discourses of forty local experts in order to establish a mapping of the most interesting wetlands from an ecological point of view.

Each of these methodologies contained different types of constraints. One could have believed that the model was going to be considered as neutral whereas the contribution of the local experts were going to be more easily subject to controversy. Actually, the critics addressed to the two methodologies did not correspond at all to this hypothesis. The marks provided by the model needed to be interpreted and this interpretation quite rapidly raised new controversies. The sensitivity of the model had to be precisely assessed. Therefore, the panel of experts felt the necessity to enlarge the network of experts in order to experiment in situ and to validate the model. Representatives from the French company of electricity (EDF), the water agencies, the Conseil Supérieur de la Pêche (a public body in charge of fishing), were integrated in the procedure of experimentation. The restructuring of the network led to changes in the model such as the taking into account of food availability, variations of temperatures or solids transport. Still, to be used as a procedure of political deliberation, the model should have incorporated one of the actors presently not represented in the existing equations: the fishers. The social acceptability of the model as a way to determine the optimal "ecological" flow - rather than the legal flow - depended on the fishers' organisations. The ministry of Environment finally authorised experimentations of the new model in several sites but this model has never been used as a decision support system to determine the "ecological flows" that should be imposed to hydraulic energy producers.

In the case of the wetlands, the methodology was completely different. The procedure was public. The methodology, the ongoing and final results were presented and discussed with representatives of various ministries, representatives of professional organisations, NGOs... The tools for the evaluation of the characteristics of the wetlands and the related management practices were not the model but two questionnaires, two case-studies and a set of interviews with the agents in charge of the implementation of environmental policies in the wetlands. The main result of this evaluation was the production of an atlas of the wetlands of national interest and a clear view of their evolution. The strategy consisting in assessing the evolutions was successful. It avoided a battle of contradictory examples. But, according to the protagonists, the evaluation failed in clearly establishing the responsibilities in the management practices leading to the progressive destruction of the wetlands. This is probably the main risk with the qualitative evaluation when the report has to be accepted by all the concerned actors. 
The two evaluations here presented clearly illustrate that the possibility to change the existing political choices with scientific expertise relies on a difficult balance between the robustness of the assessment methodology and the representation of the pluralistic concerned groups and interests. The political public policy communities aiming at implementing an integrated water management will always be confronted to these structural choices. The analysis of the new legislation on water management (law of 30 December 2006) reveals that these evaluations led to contrasted results. For sure, the structure of political opportunities as now changed. The new legislation will authorise the negotiation of a specific river flow for each river. However the law does not indicate the way to calculate the flow that will enable to reach the good ecological status. Only the future will tell whether this legislation result in endless conflicts between river users and energy producers or if, at a territorial level, political communities will emerge and produce a legitimate expertise on annual variable flows. Anyway, the available modelling tool will have to be adapted to each river context and validated by the local stakeholders. Concerning the preservation of the wetlands the law states that the "wetlands of national interest" have to be taken into account in the territorial planning procedures $^{8}$. In that case also it will be of great interest to analyse the opportunities, generated for local governments, research networks and other stakeholders, to build territorial political communities around specific wetlands.

\section{Conclusion}

The analysis of the various cases of water policy formulation here considered revealed that the possibility to produce an integrated expertise (e.g. an expertise favouring a good balance between the concerned interests and the preservation of the aquatic ecosystem) depended on the existence of a political public policy community. Such a community did not exist when eutrophication came on the political agenda. On the contrary, there were groups of administrative agents and scientists cooperating when came the time to assess the compulsory river flows and the management of the wetlands. These groups took the opportunity of the procedures of public policy evaluation (institutionalised by that time) to build political communities that were able to produce rather integrated expertises. But the existence of these political communities is not the end of the story and we noticed that, in each case, the methodological choices led to very different results. The

\footnotetext{
${ }^{8}$ However, the management of wetlands, their protection and valorisation is the purpose of public policies through other legislation (Law on the Development of the Rural Areas DTR no. 2005157, February 2005, Law on the agricultural sector no. 2006-11, January 2006) and through specific bodies at a national level (An institute in charge of monitoring the wetlands evolution since March 1995) or at a regional scale (a technical committee in charge of the wetlands in the Rhone-Méditerranée-Corse watershed).
}

integration of the interests was undoubtedly the largest in the case of the wetland management whereas it stayed hypothetic in the case of the river flows because of the lack of consultation with the fishers. On the contrary, the evaluation of the river flows relied on a modelling tool which could generate a radical change in the management of the river flows whereas the methodology used in the case of the wetlands only led to marginal changes in their management.

The political public policy communities studied in the Sect. 3 of this paper are of course much more subject to changes than the intellectual public policy community studied in the previous section. It was precisely the aim of the scientists and administrative agents involved in the two policy evaluations to integrate new stakeholders. By the way the procedures of expertise got more complex and political negotiations could occur. In the case of river flows, the difficulty was to integrate new stakeholders able to discuss the modelling assumptions. In the case of the wetland management, the challenge was more to keep the stakeholders associated at the origin of the procedure within the community, in order to make them accountable for their activities.

However, these two cases of river flows and wetland management were quite significant of the evolution of the role of experts in the water management sector. When the structure of political opportunities is favourable, the scientists involved in the expertise procedures are more and more mediators rather than only experts who have to decide on an issue according to their specific knowledge (Roqueplo, 1997). These new experts have to develop tools in collaboration with the concerned actors. More and more often they are and have to be part of a political community and to play a very active role in this community.

But scientific experts are also more and more part of intellectual public policy communities. As explained in the Sect. 2, it was partly in the framework of these intellectual communities that the right modes of public action and the good practices and objects of research were discussed and validated. The main finding of the presented research was that the user was lacking in these intellectual public policy communities. Nonetheless the integration of the final user might probably favour real multidisciplinary researches. This reflection on the final user identification and on the best way to integrate him in the community has begun in some places in France such as the PIREN Seine (Interdisciplinary Research Program on the river Seine) or the Conseil Regional d'Ile de France (The Great Paris Council). Environmental protection organisations are now involved in the elaboration and implementation of some research programs ${ }^{9}$. But the co-production of science by citizen and scientists is still an open issue.

\footnotetext{
${ }^{9}$ Such as the Partenariat Institutions Citoyens pour la Recherche et l'Innovation "Vers une gestion citoyenne de l'eau en Ile de France", http://www.picri.h20.net.
} 
Edited by: S. Barles

\section{References}

Callon, M., Lascoumes, P., and Barthe, Y.: Agir dans un monde incertain, Essai sur la démocratie technique, Seuil, 2001.

Carbiener, R.: Compositions lessivielles avec ou sans phosphates et protection des milieux aquatiques, Rapport au secrétaire d'Etat auprès du premier Ministre chargé de l'Environnement, 1990.

Comité interministériel de l'évaluation des politiques publiques, Commissariat au Plan: Les zones humides, Rapport d'évaluation, edited by: La Documentation Française, Paris, 1994.

CSI - Lyonnaise des Eaux Dumez, Association pour le Progrès du Management: Une entreprise face à ses innovations: politique, technique, environnement, Les fondements organisationnels et culturels de l'innovation dans les services, 1996.

Doussan, I.: Activité agricole et droit de l'environnement, l'impossible conciliation, L'Harmattan, Logiques Juridiques, 2002.

Doussan, I.: Droit, agriculture, environnement: bilan et perspectives ou dépôt de bilan en perspective?, Droit de l'Environnement, 99, 156-162, 2002.

Duran, P. and Thoenig, J.-C.: L'Etat et la gestion publique territoriale, Revue Française de Science Politique, 46(4), 580-623, 1996.

Edelman, M.: Pièces et règles du jeu politique, Seuil, Coll. La couleur des idées, Paris, 1991.

Flory, J. C.: Les redevances des agences de l'eau, Rapport au Premier Ministre et à la Ministre de l'Ecologie et du Développement Durable, Octobre 2003.

Fontaine, J. and Hassenteufel, P. (Dir.): To change or not to change? Les changements de l'action publique à l'épreuve du terrain, Rennes, Presses Universitaires de Rennes, 2002.

Garraud, P.: Politiques nationales: élaboration de l'agenda, L'Année Sociologique, 40, 17-41, 1990.

Gaudin, J.-P.: Gouverner par contrat. L'action publique en question, Presses de Sciences Po, 1999.

Inspection Générale des Finances - Conseil Général du Génie Rural, des Eaux et Forets - Comité Permanent de Coordination des Inspections: Rapport d'évaluation sur la gestion et le bilan du Programme de Maîtrise des Pollutions d'Origine Agricole, vol. 1, rapport de synthèse, July 1999.

Jordan, A. G.: Sub-governments, policy communities and networks: refilling the old bottles, J. Theoret. Politics, 2(3), 319$338,1990$.
Jordan, A. G. and Richardson, J. J.: Government and pressure groups in Britain, Oxford Clarendum Press, 1987.

Kessler, M. C., Lascoumes, P., Setbon, M., and Thoenig, J. C. (Dir.): Evaluation des Politiques publiques, L'Harmattan, Coll. Logiques Politiques, Paris, 1998.

Latour, B.: La science en action, La découverte, 1989.

Lascoumes, P. and Le Bourhis, J.-P.: Le bien commun comme construit territorial, Identités d'action et procédures, Politix, 42, 3766, 1998.

Leca, J.: L'Etat creux, in: François d'Arcy, Luc Rouban: De la Vème République à l'Europe. Hommage à Jean-Louis Quermonne, Paris, Presses de Sciences Po, 1996.

McAdam, D., McCarthy, J. D., and Zald, M. N.: Comparative perspective on social movements, Political opportunities, mobilizing structures, and cultural framings, Cambridge, Cambridge University Press, 1996.

Mermet, L.: Dans quel sens pouvons-nous gérer l'environnement?, Annales des Mines, 22, 68-81, 1991.

Neboit-Guilhot, R. and Davy, L.: Les Français dans leur environnement, Nathan, Paris, 1996.

Nelkin, D. (Ed.): Controversy, Politics of technical decisions, third edition, SAGE Publications, 1992.

Perret, B.: L'évaluation des politiques publiques, La Découverte, Coll. Repères, Paris, 2001.

Roqueplo, P.: Entre savoir et décision, L'expertise scientifique, INRA, Editions, Paris, 1997.

Sabatier, P. (Dir.): Theories of the Policy Process, Boulder, Westview Press, 1999.

Secrétariat d'Etat auprès du Premier Ministre chargé de l'Environnement et de la Prévention des risques technologiques et naturels majeurs, Direction de la Protection de la Nature, Service de la pêche et de l'Hydrobiologie - Centre National du Machinisme Agricole, du Génie Rural, des Eaux et Forêts, Division hydrologie, hydraulique fluviale et souterraine, Division qualité des eaux, pêche et pisciculture: Synthèse technique sur le bilan d'application de l'article L 232-5 du Code Rural, Première partie: Hydrologie et usages de l'eau, Deuxième partie: Hydrobiologie et débits réservés, June 1990.

Souchon, Y., Trocherie, F., Fragnoud, E., and Lacombe, C.: Les modèles numériques des microhabitats des poissons : applications et nouveaux développements, Revue des Sciences de l'Eau, 2, 807-830, 1989.

Stengers, I.: L'invention des sciences modernes, La Découverte, Paris, 1993.

Valiron, F.: Gestion des eaux. Principes, moyens, structures, Presses de l'Ecole Nationale des Ponts et Chaussées, Paris, 1984. 